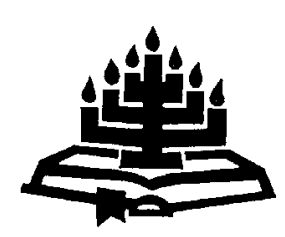

\title{
Athaliah, a treacherous queen: A careful analysis of her story in 2 Kings 11 and 2 Chronicles 22:10-23:21
}

Robin Gallaher Branch

School of Biblical Sciences \& Bible Languages

Potchefstroom Campus

North-West University

POTCHEFSTROOM

E-mail: sbbrgb@puk.ac.za

robingbranch@yahoo.com

\begin{abstract}
Athaliah, a treacherous queen: A careful analysis of her story in 2 Kings 11 and 2 Chronicles 22:10-23:21

This article presents a critical look at the story of the reign of Athaliah, the only ruling queen of Israel or Judah in the biblical text. Double reference in 2 Kings and 2 Chronicles shows her story's importance and significance to the biblical writers. The largely parallel accounts read like a contemporary soap opera, for they contain murder, intrigue, harem politics, religious upheaval, and coup and counter-coup. Her story provides insights on the turbulent political climate of the ninth century $B C$. However, the purpose of the biblical writers is not to show Athaliah as the epitome of evil or that all women in power are evil.
\end{abstract}

\section{Opsomming}

Atalia, ' $n$ verraderlike koningin: ' $n$ noukeurige analise van haar verhaal in 2 Konings 11 en 2 Kronieke 22:10-23:21

In hierdie artikel word die verhaal van Atalia krities nagegaan. Atalia was naamlik die enigste koninging van Israel of Juda wie se regeringstyd in die Bybelteks verhaal word. Die dubbele verwysings na hierdie tyd in 2 Konings en 2 Kronieke dui op die belangrikheid en betekenis van haar verhaal vir die Bybelskrywers. Die twee weergawes wat grotendeels parallelle weergawes is, lees byna soos 'n hedendaagse sepie, want hierdie verhale sluit elemente in soos moord, intrige, harempolitiek, godsdiensopstand, staatsgreep en kontrastaatsgreep. Atalia se 
verhaal gee insig in die onstuimige politieke klimaat van die negende eeu voor Christus. Die doel van die Bybelskrywers was egter nie om Atalia te teken as die beliggaming van die bose nie, of om te impliseer dat alle vroue wat mag het, boos is nie.

\section{Introduction}

The biblical story of Athaliah, the only reigning queen of either Israel or Judah, while not flattering or happy, is filled with insights on the turbulent political climate of the ninth century BC.1 Athaliah, born into the house of Omri, followed Baal. ${ }^{2}$ Double reference to her story in 2 Kings 11 and 2 Chronicles 22:10-23:21 shows its importance and significance to the biblical writers as part of their discussion or "chronicling" of the history of the reigns of the rulers of Judah. The largely parallel accounts present revolting, horrific insights into the lives of the royal family. Broadly speaking, the emphasis on 2 Kings is on recounting the historical content while that of 2 Chronicles is on presenting the theological validity of those in the Davidic line as the rightful heirs of Judah. In both accounts, daily life in the royal Judean court comes across like that of a contemporary soap opera, for it contains elements of murder, intrigue, harem politics, religious upheaval, coup, and counter coup. How did this seamy state of affairs come about? The narrators' answer, consistent with the voice of the prophets, is apostasy. 3 The two accounts pivot around Athaliah, a woman from whom history recoils in horror but whom,

1 Athaliah is the only reigning female monarch recorded in Scripture; no other Israelite or Judean woman managed to become queen again until the Second Temple era when Salome Alexandra reigned, 76-67 BC. Salome Alexandra ascended the throne after the death of her second husband, Yannai. She earlier had been the wife of his brother, Aristobulus I; since that union ended without issue, she was required to marry Yannai in accordance with the laws of Levirate marriage. The Rabbis praise her nine-year reign as a time of piety, peace, and prosperity, a time when wheat, oats, and lentils grew to extraordinary sizes (Anon, 1971b:691-693).

2 Perhaps because she followed Baal she is omitted from the genealogy of Jesus in Matthews 1:1-17. The genealogy mentions five women: Tamar, Rahab, Ruth, the wife of Uriah, and Mary. Tamar, Rahab, and Ruth are non-Israelites who nonetheless contribute significantly to the biblical text and the life of the faith community.

3 The prophets repeatedly chastise Judah for forsaking Yahweh; early references are 1 Kings 3:2 and 22:43. 
upon careful examination, the narrators present quite straightforwardly. 4

Through Athaliah, a major character in these chapters, the narrators show the political climate of the ninth century; set up a series of contrasts largely of good and evil; and stress the political and theological vacillation of the people. The narrators' purpose, however, is not to show that Athaliah is the epitome of evil or that all women in power are evil.

In discussing these things, this article employs a literary methodology; it looks at elements like characterisation, setting, plot, conflict, narrators' viewpoints and central idea. The central idea of the passage is to delegitimise Athaliah and to legitimise her successor, the young boy Joash, the only survivor of David's line (Lostracco \& Wilkerson 1998:1).

\section{Background history and textual highlights}

Athaliah came to Judah from the Northern Kingdom. Texts call her alternately the daughter of Omri (2 Chron. 22:2); and daughter of Ahab (2 Kings 8:18). If the latter, Jezebel was her mother Anon, 1971a:814). Athaliah married Jehoram, son of righteous Judean king Jehoshaphat, around 865 BC. 5 Their marriage reflects the influence of Omride Israel over a weaker Davidic Judah (Dillard, 1987:174). Bright (1981:242) believes the marriage alliance was a friendly treaty between equals. 6 Its military and commercial benefits included an attempt to revive overseas trade out of Ezion Geber (1 Kings 22:48).

When Jehoram assumed the throne in $849 \mathrm{BC}$, he put all his brothers and some princes of Israel to the sword (2 Chron. 21:4); significantly, they were loyal Yahwists.7 Bright (1981:252) acknow-

4 Kaufmann ( 1 1947:485) calls her a murderer and usurper of the throne.

5 Barrick (2001:9) notes many textual genealogical difficulties in the relationships of Jehoram and Ahaziah of Judah to each other, to their predecessor Jehoshaphat, and to the House of Omri. He (Barrick, 2001:20) posits that Athaliah married Jehoram's elder brother, Jehoshaphat's actual first-born and heir-apparent son, who then predeceased them both.

6 Lockyer (1967:32) disagrees, saying Jehoshaphat's giving of his son Jehoram to Athaliah in marriage was "a blot on his otherwise good memory".

7 Solomon set a historical precedent for this fratricide at the beginning of his reign by ordering the death of his half-brother Adonijah. Solomon interpreted Adonijah's request for Abishag, their father David's concubine, as a bid for the 
ledges that the text has "not a shred of proof for it" but nonetheless wonders if Jehoram's slaughter of his brothers was not prompted by his wife "because she felt her own position so insecure". 8 If it does, it foreshadows her subsequent acts of infanticide. Bright's speculation, therefore, is noteworthy.

Jehoram reigned in Jerusalem eight years until $841 \mathrm{BC}$; he did evil in the eyes of the Lord and "passed away, to no one's regret," the text quips (2 Chron. 21:6, 20). Ahaziah, the son of Jehoram and Athaliah, succeeded him and reigned one year, 841-840 BC/BC. ${ }^{9}$ Ahaziah's ill-timed visit to his cousins in Israel coincided with the Jehu's putsch/coup. Jehu killed Joram, who had succeeded his father Ahab as king of Israel. Jehu pursued Ahaziah and wounded him; Ahaziah died at Megiddo, according to 2 Kings 9:27.10

Sometimes scholars tend to harmonise the accounts in Kings and Chronicles by saying they overlay each other. Generally, the results are unsatisfactory (Dillard, 1987:173). For the purposes of this article, however, Jehu's purge and its subsequent effects on Judah and Israel serve to show the turbulence of the ninth century. ${ }^{11}$ Murder is arbitrary, based on blood, alliance, and thirst for power.12 The period seems to have been one of lawlessness within the

throne (see 1 Kings 2:13-25). Fratricide, however, has a long biblical tradition. Cain killed Abel and Joseph's brothers hated him so much that they almost killed him (see Gen. 4:37:20).

8 See also Anon (1971a:814).

9 With Athaliah as a mother, Ahaziah never had the chance to develop any finer qualities of character, Lockyer (1967:32-33) writes. Brenner (1985:31), however, admires her for the various roles she played throughout her life as king's daughter, king's wife, king's mother, intimate adviser to her son Ahaziah, a king and regent after his death.

10 The differences regarding the events surrounding the death of Ahaziah are among the most difficult textual questions in the Old Testament. See Dillard (1987:172) for an excellent explanation.

11 Bloody conditions prevailed, as Jehu's maneuvers against the house of Omri indicate. For instance, Jehu cleverly had others, the officials of Jezreel, execute his potential rivals and contenders to the throne: the 70 sons of Ahab who were being reared in Jezreel. He then killed all those who remained loyal to the house of Ahab plus Ahab's chief advisors, close friends, and priests, in short "leaving him no survivors" (2 Kings 10:1-11).

12 Yet Jehu was commanded by Yahweh and anointed by Elijah to obliterate the house of Ahab (1 Kings 19:16-17). Later, he was commended for carrying out God's instructions against Ahab (2 Kings 10:30). Athaliah, meanwhile, received no commission to exterminate her house and certainly no divine praise for doing so. 
political establishment, somewhat reflecting an earlier period of Israel's history "when Israel had no king and everyone did as he saw fit" (Judges 21:25).

Of note, however, is that the texts of Kings and Chronicles seem to differentiate between segments of the populace, breaking them down to the people of the land (וכָל-עַם דָאָרָץ) (2 Kings 11:14) and the

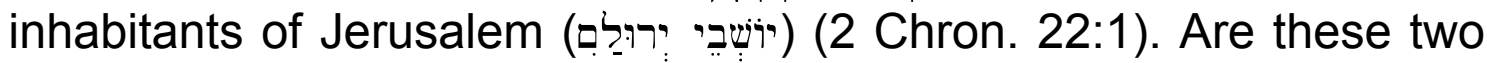
political groups pitted against each other, or are they merely synonymous? The text lacks clarity.

When Athaliah hears of her son Ahaziah's death by Jehu, according to the accounts in 2 Kings and 2 Chronicles, she destroys the entire royal family. The rabbis add that these violent deaths serve as punishment for David's having kept himself in safety while his army fought against Absalom (Ginzberg, 1968:6, 268). Perhaps she consciously copies Jehoram's earlier massacre, as Bright (1981: 252) suggests. Her plan fails, however, for one escapes. The texts recount the heroic rescue of year-old Joash and his nurse by Jehosheba, the wife of Jehoiada the priest; Jehosheba is Ahaziah's older half-sister. Presumably, Jehosheba is not the daughter of Athaliah but the daughter of Jehoram and another wife. The texts leave unanswered the natural question of why Athaliah allows Jehosheba to live and not be slaughtered along with others in the royal line. Jehosheba and Jehoiada, the two loyalists and believers in Yahweh, hide the baby and his nurse in the temple.

Six years later Jehoiada orchestrates an elaborate coup involving the Carites, priests, Levites, palace guard, and army. Surrounded by armed protection, Joash, now seven, is led out and loudly proclaimed king. The cheering alerts Athaliah who comes to see what is happening; she sizes up the situation, tears her garments, and shouts her sole words in the chapters, "Treason! Treason!" (קשׁשר קְשֶר ) (2 Kings 11:14; 2 Chron. 23:13).

Jehoiada orders her taken out and killed by the gate where the horses enter. She, a follower of Baal, is slain outside the Temple to save it from being defiled. Next, Jehoiada re-establishes two covenants, the first between the Lord and the king, and the people, and the second between the king and the people. The people then rampage, tearing down the temple of Baal and killing Mattan, the priest of Baal, in front of the altars (2 Chron. 23:17; 2 Kings 11:18). ${ }^{13}$

13 The more detailed account in 2 Chronicles adds several theological insights. God brought Ahaziah's downfall and there was no one strong enough to retain the 
In marked contrast to many other narrational texts, both 2 Kings and 2 Chronicles make use of opposites, a literary tool. These include good and evil, murder and salvation, death and life, injustice and justice. By the end of the chapter, Joash lives and reigns, and Athaliah's kingdom turns from her and is torn from her just as she tears her own garments. Beginning in murder, her career as reigning monarch ends with the same.

\section{Use of language}

Both accounts of Athaliah's reign are set within the context of God's faithfulness to his people and his promise to David that David's line will never lack a male descendant (2 Sam. 7:1-17; 1 Kings 8:20; 1 Chron. 17:1-15). Athaliah's story immediately arrests attention because the readers and hearers know her presence on the throne violates God's promise: she is not a member of David's house. The Chronicles' version continues the chronicler's pattern of presenting a Levitical sermon on God's faithfulness followed by a human example illustrating a person's faithfulness or unfaithfulness (Blenkinsopp, 1993:29-30). Chronicles seesaws between high points of faith like Jehoshaphat's response to an upcoming attack from Moab and Ammon (2 Chron. 20) and a deliberate choice of wrongdoing like the story of Athaliah's murders. ${ }^{14}$ In its emphasis on Israel's exile and restoration, it recounts stories of individuals that illustrate the overall success or failure of their relationship to the Lord (Allen, 1999:301). These stories are thought to have addressed a new community, lately returned from exile and facing difficulties and discouraging and compromising situations (Hamilton, 2001:478-479).

Syntactically, Athaliah's story in 2 Kings begins with an arrangement typical of the book: the waw (1) is followed by a subject and the perfect tense (see also 2 Kings $11: 1 ; 3: 1 ; 4: 1$, 38, 42; 5:1; 6:8; 8:1 and 9:1) (Hobbs, 1985:136). A check on these references indicates they cannot be signs heralding only evil or only good; they are merely narrative forms of introducing a new topic and not narrative clues signifying a momentous event for blessing or for ill. ${ }^{15}$

kingdom after him (2 Chron. 22:7, 9b). Into this political vacuum walks Athaliah who takes over, but only for six years until "Jehoiada showed his strength" (23:1). Jehoiada's well-planned takeover involves numerous members of the army and gains added legitimacy by the use of David's shields and spears (23:9-10).

14 Von Rad (1966:267) posits that the writer of Chronicles used extreme examples to encourage subsequent generations to remain loyal to Yahweh.

15 Hobbs (1985:136) breaks 2 Kings 11 down to two large sections. Verses 4-12 reflect a priestly account of the fall of Athaliah; the people's perspective is 
Furthermore, the first verse in 2 Kings 11 lends itself to ambiguity because Athaliah's name carries a theophoric component of Yahweh. Is she for or against Yahweh? Her very name, which may combine "to grow large" and "to be exalted" with Yahweh, is ironic because, as the reader quickly learns, she has spent her life erecting temples to Baal (Hobbs, 1985:138). ${ }^{\mathbf{1 6}}$ Irony appears several other times in both accounts, emphasising the narrators assumed their audience knew the historical details of Athaliah's story.

The importance of other verbs in the Kings' passage should not be overlooked. Hobbs (1985:137) points out that the sceptre of leadership passes to Joash via a series of verbs which show the political genius of Jehoiada: he sent (של I ) (v. 4), he ordered (v. 5); he

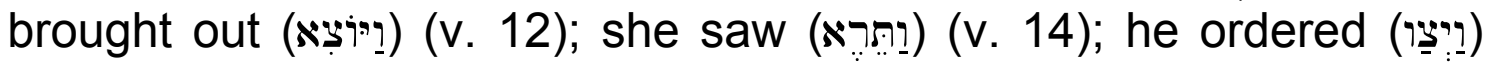
(v. 15); and she died (Iיתוּן (v. 16). Verbs constitute an essential part of any writer's arsenal of diction, for they carry a wealth of specific meaning (Lostracco \& Wilkerson, 1998:35).

The narrators allow Athaliah only two words, and they are loaded with political, theological, and historical meanings. Athaliah shouts, "Treason! Treason!" (2 Kings 11:14; 2 Chron. 23:13). She tries to interrupt the coup with these words, but the switch to another's leadership already has been made. The repetitive use of treason displays irony because treason surely has occurred twice. The first time was by Athaliah's own murderous hands. The second time - at least from Athaliah's perspective - is happening to her right now: Jehoiada is usurping her reign via a coup.17

presented in verses 13-18. Nelson (1987:209-210), however, says verses 1-12 are the climax of the narrative and verses 13-20 show the results.

16 Added to the puzzle surrounding her name is the light it sheds on her father Ahab's spiritual condition. Ahab named three of his children with names compounded with Yahweh - Athaliah, Ahaziah, and Jehoram (James, 1939:172). Earlier texts present Ahab ambiguously as both one who repents (1 Kings 21:2729 ) and yet one who is judged as doing more evil in the eyes of the Lord than any king before him (1 Kings 16:30).

Athaliah's name, however, has no Hebrew root. Scholars think it may be derived from the Akkadian meaning "Yahweh has manifested his glory"; likewise, it may have an Arabic derivation meaning "bulky" or "robust" (Thiel, 1992:1:511). It could mean "Taken away from the Lord" or "Yahweh has afflicted" (Lockyer, 1967:32). Yet scholars agree that there is no other biblical woman's name with a theophoric component of Yahweh in it (Thiel, 1992:1:511).

17 See Alter (1981:88-113) for a more detailed account of the use of repetition throughout the Hebrew Bible. 
Another time kesher (קֶֶׁ) is used in the Hebrew Bible is in relation to Zimri who rebelled against Elah, reigned seven days, and died by setting fire to the palace around him (1 Kings 16:15-20). The ironic connection between his story and Athaliah's is further established when the reader remembers that Jezebel, certainly Athaliah's mentor and perhaps mother, taunted her assassin Jehu by comparing him to Zimri (2 Kings 9:31).

Another literary tool is omission. Athaliah's reign lacks a formal, formula introduction in both texts. Possibly, the narrators reinforce its illegitimacy by declining to introduce her in the dignified manner they accord other monarchs. That these monarchs all are kings seems secondary, arguably, to their view that Athaliah's reign usurps the rightful Davidic line. Consequently, the narrators' expected introductory formula falters. ${ }^{18} \mathrm{Her}$ reign is not presented as starting in the blank year of blank king of Israel; her age is not given; the length of her reign, six years, surfaces only because it corresponds to the time her grandson Joash stays hidden in the temple; finally and surprisingly, the narrators do not comment on her as one doing evil or good in the eyes of the Lord. In these ways, the narrators stress the legitimacy of her predecessor, David, and successors, Joash and Hezekiah; on the whole, their reigns are judged favourably (2 Kings 12:2; 18:3). Similarly, the reigns of Zimri and Omri, and Ahab are judged unfavourably (2 Kings 16). In short, the narrators present Athaliah's reign in compressed historical form as an unfortunate interlude in the Davidic dynasty (Hobbs 1985:138). Its irregularity, its illegitimacy, its usurpation, and its inevitable doom are emphasised by the lack of respect the narrators show in introducing her tenure.

\section{Narrative tools}

Both 2 Kings and 2 Chronicles utilise contrasts and comparisons as their primary narrative tools. The narrators present absolutes of right and wrong. They portray two distinct courses for the people of Judah to follow: the worship of Baal or the worship of Yahweh. Since the biblical writers unabashedly favour the latter course, the two accounts of Athaliah abound in narrative contrasts to which a reader naturally might assign the value judgments of good and evil. The narrators add a twist to the timeless literary formula of good triumphing over evil by embellishing the good by encasing it in the innocence of a six or seven-year-old orphan.

See 1 Kings $16: 1 ; 17: 1 ; 18: 1 ; 21: 1$. See 2 Chronicles $25: 1 ; 26: 1 ; 27: 1 ; 28: 1$. 
The narrators add a further twist by recording Athaliah's story in a way similar to many of the terse vignettes presented so succinctly in Proverbs: no doubt is left there about the views of the writer of Proverbs of right and wrong. Certainly no grey areas exist. As in Proverbs, one has to search for middle ground in Athaliah's story.

With broad brush strokes, the narrators pit the Yahwists against the Baalists, the rightful ruler against the unrightful one, the house of David against the house of Omri, Judah against Israel, monarchy against dictatorship, truth against deception, the passive against the active, the agrarian countryside against the city, life versus death, swift justice versus outright murder, and the alliance of a courageous woman and her husband against the usurped power of a wicked queen.

Within these contrasts the narrators utilise silence, one of their favourite devices, as a narrative tool. They divulge no descriptions about life - whether palace, city, or countryside - in those six years, nothing about agriculture, climate, international intrigue, or highlights of Athaliah's reign. Wars, if any, go unmentioned. Silence dominates. Why? The narrators choose to focus on the illegality of this queen's reign. She is not the anointed monarch.

An additional narrative tool they use is a glimpse or hint of court intrigue. Out of all Ahaziah's children, why did Jehosheba select Joash? Was it because he was the smallest? Was he nearest an escape route and therefore the easiest to carry to safety? The narrator fails to say. Yet Jehosheba undoubtedly knew Joash's mother Zibiah hailed from Beersheba some 40 miles south of Jerusalem (2 Kings 12:2); distance from Jerusalem clearly allows for a modicum of safety. By Jehosheba's choice, the inherent rivalry of co-wives and their offspring and struggles over the throne's succession continue in this saga, something surely reminiscent of David's legacy.

\section{Characterisation}

The narrators carry out the theme of contrasts by drawing strong characters in both accounts. Because the characters are polarised in terms of worship of Baal or Yahweh and pitted against one another politically as representatives with loyalties to Israel or Judah and to Omri or David, the reader knows the upcoming conflict must produce only one survivor. There is a no win-win scenario in this chapter; the stakes - political, personal, and theological - are too high. 
Athaliah: Who is Athaliah? Actually, she enjoys one of the longest narrative careers in Scripture because the texts mention her as daughter, wife, mother, dowager queen, and queen.19 She carries out a complex set of roles. The first scholarly controversy around her is whose daughter is she anyway, for she is referred to as the daughter of both Omri and Ahab. Although called a daughter of Omri in 2 Kings 8:26 and assumed to be the daughter of Ahab his son and Jezebel whom he married (2 Kings 8:18 and 2 Chron. 21:6), scholars solve this difficulty by deciding she is the daughter of Omri and sister of Ahab (Thiel, 1992:1:511). The discrepancy, "daughter of Ahab," is explained as being a scribe's later addition, for she is referred to as the sister of Ahab in the LXX.

Katzenstein (1955:197) believes she was born in 881/880 BC/BC, near the time Omri ascended the throne and she was the daughter of Omri, sister of Ahab, and pupil of Jezebel.

Although her parentage contains discrepancies, what is undisputed in the texts, however, is that her marriage was a political alliance. Love is not mentioned in the match between Athaliah of Israel and Jehoram of Judah, son of Jehoshaphat.20 The union of Jehoram and Athaliah evidently eased the tensions between Israel and Judah prevalent since Solomon's time. ${ }^{21}$ Scholars speculate the political payoffs of the brokered marriage included Israel's giving back areas of Benjamin in exchange for Judah's taking a backseat politically to the stronger Israel (Thiel, 1992:1:512). If the Jerusalem nobility negotiated the marriage, then it had too much at stake politically to back out during the turmoil of Jehu's purges and likely supported both her coup and her reign. Significantly, neither Kings nor Chronicles addresses Athaliah as a gebira. The root, gbr, carries connotations of power, strength, and dominance and probably means great lady or principal lady rather than queen mother, as it is usually translated (Bowen, 2001:598).

19 As such she can be compared to Miriam, the sister of Moses and Aaron, whose life is recorded as a child, prophetess, and co-deliverer with her brothers of the Israelites from Egypt (Ex. 2:1-10; 15:20; Num. 12; Micah 6:4).

20 Nor is it mentioned in context with the marriages of all the other kings of Israel and Judah except one. The text says King Solomon loved many foreign women (1 Kings 11:1).

21 Kaufmann (7-ח 1947:233) writes that in the days of the kingdom of Judah, Baal worship existed in the royal family for many years. 
Brenner (1985:29) assumes that Athaliah's position in Jerusalem for years was not unlike that of any other chief wife: she was consort and mother.22 The text certainly refrains from commenting much on her life prior to her husband's and son's deaths. During her son's lifetime she, as dowager queen mother, seems to have been a strong person, one who gave advice and one who exercised authority (Brenner, 1985:29). Brenner, however, ignores the narrator's comment that during Ahaziah's reign, Athaliah acted as her son's guide in wrong-doing (2 Chron. 22:3).

Upon hearing of Ahaziah's death, Athaliah seizes the moment. Carpe diem! epitomises her motto. She consolidates her reign by executing her rivals, almost the entire Davidic line in Judah. Scholars enjoy speculating on her intentions. Josephus (1981:IX, VII. 141) wryly credits her with an opportunistic nature while Lockyer (1967:33) attributes Athaliah's rise to the throne to envy. ${ }^{23}$

Camp, however, renders a more charitable opinion, reasoning Athaliah fears for her own life when Ahaziah is killed, Camp (1992:104) believes Athaliah then acts in the only way such logic leads. Cut off from her family's power base in Israel and from any means of retreat or escape, she preserves her life via murder (Camp, 1992:104). Camp's view takes into account the political situation in Israel. Jehu likewise clearly took charge via assassination, murder, and terror. Andreasen (1983:190) adds Athaliah carries out her action undoubtedly with the knowledge and support of the pro-Israelite (i.e., pro-Omri) faction in Jerusalem (2 Kings 9:16). But Schulte (1994:136) believes her murderous rampage ultimately cuts off her own legitimacy as queen mother; certainly it sows seed for her own downfall.

The influence of a queen mother in Judah and Israel seemed to follow the pattern of the Hittite and Ugaritic cultures and other near-Eastern cultures (Andreasen, 1983:182). In general, a queen mother's power was independent of that of her husband, the king, or her son, the king. If her husband predeceased her, she served as regent. If he was absent, she acted in his stead. Throughout, she had a pre-eminent role in the cult (Andreasen, 1983:182). Ben-Barak (1994:175) sees Athaliah's seizure of the throne as evidence showing that considerable power had accrued to the station of queen mother.

23 Jewish tradition equates Athaliah's purge with Saul's slaughter of the priests of Nob. The rabbis say Athaliah's reign of terror was how God exacted payment from the House of David for his transgression in connection with the extermination of the priests at Nob (Ginzberg, 1968:4, 257-258). Even as Abimelech solely survived the sword of Saul, Joash alone survived his grandmother's rampaging bloodbath. 
Ben-Barak (1994:177) agrees with Camp that Athaliah acts in selfpreservation, but emphasises her seizure of power was an act of desperation, one consistent with her family's history of murder and fratricide. Ben-Barak (1994:177) justifies Athaliah's infanticide by asserting her action was entirely understandable in the light of the annihilation of the royal family in the northern kingdom and the murder of her son and of all the king's brothers.

But Camp, Ben-Barak, and Brenner fail to see that murder never justifies itself in the biblical text. While murder may be recounted by a narrator without emotion, retribution falls eventually on the one with the bloody hand. Cain's murder of Abel gives the scriptural precedent; Cain, marked on his forehead, is banished (Gen. 4:1-16). Athaliah fails to remember that Jezebel's murder of Naboth set in motion the prophecy that dogs would devour her by the wall of Jezreel (1 Kings 21:23; 2 Kings 9:10, 34-36).

Yet clearly Athaliah's murder of her family, a political purge, solidified the throne under her for a season. 24 Athaliah - daughter of a king, sister of a king, wife of a king, mother of a king - was now queen in her own right. But did her assassinations carry a theological goal, too? Did she so hate the God of Judah that she wanted to exterminate the Davidic line, the line through which the Messiah would come? The text remains silent.

But if nothing else, the murders helped Judah deteriorate politically and theologically in the narrators' eyes. For evidence of this, the Rabbis cite the absence in the days of Athaliah of the greeting, "The Lord bless you", a salutation common in the days of Boaz and Ruth (Ginzberg, 1968:6, 191; Ruth Rabbah, 1939:4.4).

The narrators heighten the sense of Athaliah's upcoming doom by recounting in detail the preparations, secrecy, and numbers involved in Jehoida's plot. The intrigue's setting takes place in the palace/ temple compound, right under Athaliah's nose, so to speak; the setting clearly enhances the story's ironic elements (Lostracco \& Wilkerson, 1998:31). Athaliah evidently remains ignorant about the manoeuvres being instigated against her by the Yahwist priest. No one tells her. No conspirator - and there are quite a few - breaks rank. This indicates she was either too isolated, too confident, or too proud; maybe power bred an arrogance and a false security. Certainly one thing Athaliah's story shows, is her failure to learn

24 Kaufman (ד-ח 1947:268) compares Athaliah's purge with the days of Manasseh, when the blood streamed down the streets of Jerusalem. 
from her mother/mentor Jezebel the importance of having a reliable network of spies and informants. 25

Her cries of "Treason! Treason!" suggest that she both saw herself as the rightful heir and immediately perceived the coup's significance. Her exclamations indicate she believed her own deception, namely that she was the rightful monarch. Her fears certainly had materialised: another heir had been found. The narrators present Athaliah as an isolated character, one duped by her own thoughts of invincibility.

Brenner (1985:30) suggests the priests lured Athaliah to the temple, something that would violently incite loyal Yahwists against her. After all, she had broken into the temple and taken its cult objects for Baal (2 Chron. 24:7). Jehoiada had reasoned Athaliah must die for the restoration to be complete, but cause for her death had to be found. Setting foot in Yahweh's temple when she was a known follower of Baal proved enough provocation.26 Amazingly, she rushes in without her bodyguards. With nobody there to protect her, Jehoiada easily orders her removal and death.

Jehosheba: Athaliah and Jehosheba offer sharp contrasts. Athaliah is a murderer, and Jehosheba is a saviour. One literally destroys and the other jeopardises her own life by rescuing a baby and his nurse.27 Although he offers no explanation, Josephus (1981:IX, VII. 1) believes Jehosheba's rescue takes place after the slaughter rather than before as the text indicates. 1 Kings 11 presents her in terms of her status: daughter of King Jehoram and sister of Ahaziah, but 2 Chronicles 22 adds an important fact crucial for the development of the story: she is the wife of the priest Jehoiada. Both texts stress what she does: she stealthily takes Joash and his nurse who are about to be murdered and puts them in a bedroom to hide them from Athaliah. Neither text describes her physically, allows her to speak, or comments on her feelings or motives; these omissions typify the biblical writers. Biblical narration typically allows actions and words to reveal a person's character.

25 See 1 Kings 19:1; 21:8, 15 - texts which show Jezebel's political acumen.

26 Slotki (1950:231) writes that levitically unclean persons were not allowed to enter the temple.

27 Although the texts present Jehosheba as a rescuer, she is not portrayed as a winner; the winners in the story, according to Fewell and Gunn (1993:167), are two males: a priest and a little boy. 
Jehoiada: The texts move quickly from contrasting Athaliah and Jehosheba to contrasting Athaliah and Jehosheba's husband, the priest Jehoiada.28 While Athaliah has a plan of accession that was evidently concocted and carried out on the spur of the moment at the news of Jehu's purge and Ahaziah's death, Jehoiada constructs a long-range plan. Their different plans show starkly different natures. They reveal Athaliah as a political novice and Jehoiada as a political savant.

Athaliah's plan is brutal, spur-of-the-moment, and effective - but negligent regarding a key element: one escapes. On the other hand, Jehoiada's meticulous plan of restoration takes in all foreseeable contingencies. Biding his time, he allows himself years to build stable, quiet, and faithful alliances. These alliances lay the groundwork for Joash's reign. Significantly, his counter coup is more encompassing than Athaliah's, for he both plans to leave no survivors of the original coup (certainly not Athaliah herself) and to reinstate the worship of Yahweh. Jehoiada covertly organises his supporters and engages in some quiet networking, according to hints in the text, during the six years the lad stays hidden.29 The pact or covenant Jehoiada makes with the guards "secured for him a solid power base from which to conduct the coup and virtually guaranteed (its) success" (Hobbs, 1985:139).

The texts prove Jehoiada adept at conspiracies. His skills as diplomat, soldier, general, and regent surface in the texts more than do his skills as priest. 30 Yet the basis of these skills is his religious training; 2 Chronicles 23:1, for instance, says he makes a covenant with the military commanders. Jehoiada's painstaking actions

28 Jehoiada appears in Scripture without prior distinction or mention, much the same as Elijah arrives suddenly in 1 Kings 17 . The narrators use the tool of unexpected introduction in both cases. Both Elijah and Jehoiada live in the real world and engage is its politics. Both men, as Yahwists, are foes of the house of Omri and the line of Ahab.

29 The narrators combine the number six with the tool of silence. They jump from the royals' slaughter to the counter-coup six years later. While no word is given about Joash's confinement, Jewish tradition maintains he and his nurse were hidden in the Holy of Holies (Ginzberg, 1968:4,258). Hobbs (1985:138), however, believes Joash was hidden in Jehoiada's bed chamber. The fact that the boy was hidden in the temple indicates Athaliah left the temple alone (Hobbs, 1985:138).

30 Yet for most of his life he served as a priest. In a discussion about offerings, the rabbis offer a clarifying contribution by Jehoiada the High Priest. "This is the general rule: what is offered for an act of sin or guilt ... must be bought there with with burnt-offerings, the flesh for God and the hides for the priests" (Babylonian Talmud, 1965:6:256) Mishnayoth. Order Moed. Shekalim. Mishnah. 
receive extensive detailing in both texts (2 Kings 11:4; 2 Chron. 23:3). ${ }^{31}$ The specific orders are not mentioned in Kings but are briefly outlined in Chronicles as dividing up the priests and Levites into thirds and stationing them at the royal palace, Foundation Gate, and courtyards (2 Chron. 23:5 ff.). The officers respond favourably and carry out their specific instructions to the letter (Hobbs, 1985: 137).

Common to both Kings and Chronicles is recognition that Jehoiada's plan involves the knowledge of several hundred men. Amazingly, all keep silent, for Athaliah herself expresses tremendous surprise at the coup. One can deduce from the numbers needed to overthrow Athaliah and pronounce Joash as king that there is dissatisfaction among the military; the narrators, surprisingly, give no reasons for it. However in contrast, the dissatisfaction of the populace seems to ignite spontaneously, fuelled by the predictable, pent-up outrage of the Yahwist priests who hate Athaliah for bringing in foreign worship. 32 Significantly, Jehoida reinstates the Davidic line instead of going back to a theocracy when God ruled through human judges.

Joash: Joash, the middle ground between the Athaliah and Jehosheba/Jehoiada polarity remains passive throughout the chapter. ${ }^{33}$ First he is saved from slaughter; then he is hidden. His childhood is not mentioned. At age six or seven he is paraded about in regal garb by Jehoiada in the palace counter purge and hailed as king. 34

31 A reconstruction of the coup is as follows: A company of the Carites guard the palace. It came on duty on the Sabbath. A second company stood guard at the Foundation Gate Sur. A third company stood guard at the palace and city entrances. Two platoons protected the king; their members did not come on duty on the Sabbath (Hobbs, 1985:140).

32 Bright (1981:252), however, believes Athaliah's cult of Baal Meqart had little following in Judah and was merely a court fad. Furthermore, Athaliah herself almost certainly had no real following; she was an outsider, a non-Davidic ruler, a woman, and one who seized the throne by an act universally regarded as criminal (Bright, 1981:252).

33 Perhaps Joash's name was prophetic. Joash received his name. He despaired, because the people despaired of having a descendant of David to occupy the throne of David (Ginzberg, 1968:6, 354).

34 Jewish lore confirms Joash's right to kingship, however, by recounting that David's large, heavy crown moulded itself and miraculously fit the lad's head perfectly (Ginzberg, 1968:4, 258). Another tradition which confirms Joash's legitimacy maintains the crown was so heavy that only its rightful wearer could support it (Ginzberg, 1968:6, 354). 
Nevertheless, Joash seems to be the only one who remains calm, surely an irony in a plot laden with tensions. Throughout the story, he stays silent, acts as directed, and takes no initiative. He stands by a pillar and receives acclaim. 35 Joash becomes active only in later texts; for example, he repairs the temple and allows the people to pay a temple tax, which they joyfully do (2 Chron. 24:1-16). But after Jehoiada, his mentor, has died at age 130, Joash waffles. He chooses wickedness and even orders the son of Jehoiada, Zechariah the prophet, to be stoned (2 Chron. 24:17-27). ${ }^{36}$

People: Athaliah's story resembles the couplets in Proverbs, a book laden with contrasts of good and evil, because one has to search for a middle ground. Surprisingly one finds this middle ground in the people; the people vacillate. Unstable in terms of theological and political allegiances, they go back and forth between Yahweh and Baal throughout both Kings and Chronicles. Arguably, the people hold out to see which side will win before making a decision about which side - both political and theological - to join. 37

Although the priests and military lead the rebellion against Athaliah, afterwards a spontaneous purge of the temple of Baal in Jerusalem is led by the people (2 Kings 11:18). Camp (1992:104) maintains the people of the land were staunch Yahwehists who never forgot the Lord and were appalled at Athaliah's religious practices. 38 Nelson (1987:209-210) agrees, but argues they are the rural gentry who remain faithful to the Davidic dynasty.

Nicholson $(1965: 59,66)$ who examines the more than 60 uses of am haeretz (עַם דָארוּץ), the people of the land, however, concludes that no one meaning for the phrase can be found. Instead of a fixed

35 However in Jean Racine's play, Joash speaks. He confronts his grandmother, shows her the dagger marks she made on his chest, refutes her curse of David's line, and vows never to forget the God of David (Racine,1960: Act Five, V 6, V 7 , 286-287).

36 Rabbinic commentary wrestles with Joash, truly a complex and tragic person in Scripture. One legend says that when Jehoiada died, the courtiers told Joash that Joash must be a god himself because he had survived living in the Holy of Holies. Joash did not rebuke them but took their message to heart and erected a monument to himself in the temple (Ginzberg, 1968:4, 258).

37 The chapters show three distinct elements in Judean society that participated in the restoration of the Davidic dynasty: the army, the priesthood and the populace (Hobbs, 1985:138).

38 Kaufman ( $\pi$ - 1947: 233) adds that the worship of Baal was seen as a foreign implant whose roots in Judah were fewer than in the Northern Kingdom, Israel. 
meaning, the fluid phrase varies from context to context (Nicholson, 1965:66). To regard it as a technical term designating a specific class or group within the population of Judah is to read too much into its meaning, Nicholson (1965:66) says.

Nicholson (1965:62) views Athaliah's overthrow as a national - and not a Jerusalem only - revolution. Nicholson (1965:62) posits that the coup, organised by Jehoida and carried out in cooperation with the army, enjoyed the backing of the nation at large. He (Nicholson, 1965:62) does not see am haeretz as an organised group but more as those in the countryside who had remained loyal to the Davidic throne. 39

The texts possibly differentiate between the people of the land (2 Kings 11:14) and the inhabitants of Jerusalem (2 Chron. 22:1). Arguably while the texts are ambiguous and might designate two different groups, the people of the land and the inhabitants nonetheless remain power brokers in Athaliah's story. Yet even if the people and inhabitants were both passive and volatile, Jehoiada calculated - and calculated correctly - they would rally behind young Joash.

Once Athaliah is taken away to be executed at the place where horses enter (2 Kings 11:16), Jehoiada begins his reforms. 40 His immediate take-charge attitude shows he had orchestrated each step of the overthrow. His first reform includes making a covenant between the Lord and the people. Actually, this is a renewal of the covenant at Sinai. The people had forgotten and forsaken it. Other covenants are between Jonathan and David; Ezra and the people and God; Moses and the people and God (1 Sam. 20:12-16; Nehemiah 8-10; Ex. 19-24). The covenants, significantly, illustrate another brilliant manoeuvre on the part of Jehoiada; they bring in those people who may have been marginal supporters of the Davidic line and make the counter coup a national, Judean event.

The quiet of the city of Jerusalem the narrators mention, may reflect several things (1 Kings 11:20; 2 Chron. 23:21). The first is peace. A coup had just taken place involving only the deaths of Athaliah and

39 Dillard (1987:173), on the other hand, claims the people of the land are associated with the landed aristocracy.

40 An irony is that Jehoiada took great care in having Athaliah killed away from the temple; but years later when his son Zechariah rebuked the Israelites from transgressing the commandment of the Lord, he was stoned to death in the courtyard of the temple of the Lord (2 Chron. 24:20-21) (Dillard, 1987:183). 
the Baal priests, but the city enjoys peace; the populace is not put to the sword. Second, the quiet may reflect shock. The people might be stunned and taken by surprise by the day's events. Third, the quiet may indicate Athaliah's remaining followers, if any, are regrouping. Nelson (1987:210), however, sees an ominous note in this quiet; he posits Jerusalem's silence represents indecision on the part of the city's inhabitants and a clear difference between them and the people of the land in terms of religious and political leanings. The texts remain ambiguous. What is clear, however, is that the people expected politics and theology to hold hands in the ninth century in both Judah and Israel. Political correctness then meant the royal families openly worshipped and maintained a theological position. The people, in general, followed the tone set by the royal houses.

\section{Comparison with Jezebel}

Does the adage "like mother, like daughter" hold for the queen of Israel and the queen of Judah? Is Athaliah Jezebel revisited? The texts invite a study of their similarities and differences. First, like her mentor or mother, Athaliah is a foreigner in Judah from Israel; Jezebel is a foreigner in Israel from Tyre. Both led their countries in the worship of Baal. Both fought openly with the followers of Yahweh.

No admiration for either Athaliah or Jezebel comes from the narrators except perhaps in subtle ways. The narrators offer a grudging praise for the length of their reigns. Athaliah reigned six years. She must have been politically astute to have survived that long, especially when others - men - lasted only weeks or brief years. $\mathbf{4 1}$ If Jezebel and Ahab were married when he began his reign, she reigned with him for approximately 21 years (874-853 BC/BC).

Yet Athaliah lacks Jezebel's intuitive intelligence. She isolates herself. Athaliah does not keep her hand on the pulse of the people or keep cultivating her power base. Therefore, her downfall is inevitable. She self-propels her own destruction. Unlike Zedekiah, another ill-fated monarch of Judah who was blinded and led in

41 In Israel, Zimri reigned seven days (1 Kings 16:15); Shallum reigned one month (2 Kings 15:13); and Pekahiah reigned two years (15:23). In Judah, Amon reigned two years (21:19); Jehoahaz reigned three months (23:31); and Jehoiachin reigned three months $(24: 8)$. 
chains to Babylon, her counsellors are not listed.42 One may presume she had none of merit or, even worse, none at all!

This begs a contrast with Jezebel. Her network of spies (howbeit unnamed) kept her informed of Elijah's victory over the prophets of Baal, her son's assassination, and Jehu's immanent arrival at Jezreel. Whereas Jezebel mastered the art of covert dealings and kept them humming, Athaliah becomes a prisoner of her own evil, one separated even from the illegitimate base of her power.

In terms of theological issues, Athaliah does not follow in the footsteps of Ahab, her father or brother, who repents at least once (1 Kings 21:27). Ahab dies a soldier's death from a wound in battle (1 Kings 22:29-36; 2 Chron. 18:28-34). But Athaliah instead copies Jezebel who fails to repent and faces death at the hands of those who have served her (see 1 Kings 22:29 ff. and 2 Kings 9:30 ff.).

Both mother/mentor/queen and daughter/queen die ignominiously and in connection with horses. Thrown from her window by eunuchs and trampled by Jehu's horses, Jezebel perishes. Similarly, Jehoida orders Athaliah hauled from the temple and slain by the sword at the Horse Gate; those who killed her probably had spend much of their lives obeying and serving her. She dies in a barnyard setting among animal refuse. 43 Like her mother/mentor in the moments before her death, Athaliah expresses outrage in vocal, defiant and aggressive terms. Like Jezebel, Athaliah dies a queen, but friendless. No one pities either queen or comes to her rescue. The text indicates no one mourns the slaying of either one. In contrast, joy breaks out in

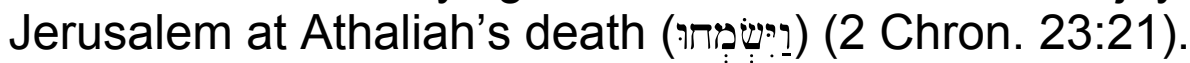

The biblical writers clearly present Athaliah and Jezebel as poor character models. In Aggadah, Jewish lore literature, these two join Vashti and Semiramis as four women who achieved power in the world (Anon, 1971a:814). But are Jezebel and Athaliah examples of evil personified as a woman? Do they become the character types of the evil, the foreign women who show up in Proverbs (Prov. 5, 6:207:27) and the prophets (Is. 47:7-8; Zech. 5:5-11)? The Hebrew Bible does not say, but a false prophetess named Jezebel (her real or allegorical name?) surfaces in the New Testament in Revelation

See Jeremiah 38:1.

43 Ironically, refuse as a theme figures in the deaths of Jehoram, Jezebel, and Athaliah. Jehoram dies of an incurable bowel disease; Jezebel's name carries the connotation of excrement in translation; and Jezebel's flesh is eaten by dogs and her body becomes like refuse in Jezreel (2 Kings 9:37). 
2:20; this Jezebel misleads God's servants by encouraging them practise sexual immorality and to eat food sacrificed to idols. Significantly, the biblical texts offer no condemnation of Jezebel and Athaliah because of their gender above what their sins of murder and idolatry merit.

\section{Scholarly views refuted}

Athaliah is uniformly viewed negatively by scholars. Consider these examples:

- "She personified the evil of her ill-famed parents and transferred the poison of idolatry into Jerusalem's veins", Lockyer (1967:32) writes. He (Lockyer, 1967:32) calls her a revolting figure, licentious, and the personification of despicable arrogance.

- The narrators hate her because she is a woman, a foreigner, a relative or daughter of Jezebel, a Baal worshipper, one who brought Baal worship to Judah, and one who is not of the Davidic line, writes Brenner (1985:29-31).

- Fewell and Gunn (1993:167) believe the texts accuse Athaliah of being responsible for her husband Jehoram's straying from Yahweh.

The texts, however, do not fully back up these scholars' views and accusations. The only emotive adjective applied to Athaliah is wicked (עַת (2 Chron. 24:7). Actually, the texts' attitude of restraint regarding Athaliah typifies the way biblical writers in general handle horrific acts, namely with detachment. The stories of Jephthah's daughter and the Levite's concubine (Judges 11 and 19) exhibit a similar lack of passion: no value judgment is made about the morality of the happenings. Instead, the proponent's activities stand alone as related; the same holds for Athaliah's story.

\section{Conclusion}

A principle throughout the Bible is that while the writers consistently condemn sin, their condemnation is gender-neutral.44 The writers

44 Trible (1973:31), wrestling with her view that the Hebrew Bible was written in a male-dominated society and its interpretation has had adverse effects on women, nevertheless believes that "the intentionality of biblical faith ... is neither to create or perpetuate patriarchy, but rather to function as a solution for both men and women". 
define sin, judge it, and record its punishment. While women leaders are few and far between in the Hebrew Bible, the text gives no indication that women are ineligible for or incapable of leadership and authority. Furthermore, the biblical writers give no indication that the leadership of women over men is somehow alien to nature (Evans, 1983:31).

Athaliah, a woman leader, violates the principles God laid down for governing his people (see Deut. 17:14-20). At the very least, she breaks the sixth commandment in attaining the throne, is not the anointed regent, and fails to write out for herself a copy of the law. These transgressions, consequently, alert the reader that her reign travels a fast track to ruin. $45 \mathrm{Her}$ reign, brief though it was, violates the divine principle of the permanence of the house of David (Allen, 1999:573).

Ruin is inevitable because she violates other key positions of Chronicles. Athaliah refuses to do the following:

- To follow the commands of the Lord to possess the good land and pass it on (1 Chron. 28:8-9). She abandons the Lord and $\mathrm{He}$ abandons her (2 Chron. 12:5).

- To humble herself, pray, and seek the Lord (2 Chron. 7:14) (Hamilton, 2001:483).

- To have faith in God and be helped; to have faith in his prophets and be successful (2 Chron. 20:20). 46

The narrators of Kings and Chronicles shed no tears lamenting Athaliah's death. Neither do they promote her story as an explanation of evil or portray her as the embodiment of the principle of evil. $\mathbf{4 7}$ Instead, Kings and Chronicles present a consistent picture regarding behaviour: reward and punishment are not overly delayed or deferred. If there is no repentance, sin sets in motion its own judgment. Punishment swiftly follows. Yahweh much earlier

45 She ranks among eight rulers within the Davidic dynasty who die violently; the others are Joram, Ahaziah, Jehoash, Amaziah, Amon, Josiah and Jehoiakim.

46 Chronicles shows that Athaliah, Ahab, Jehoram, and Ahaziah do not follow these commands. Therefore, they all fail. Jehoshaphat and Hezekiah do; therefore, they succeed.

47 See Brueggemann (1982:41) for a fine discussion of the Old Testament's existential approach to evil. He (Brueggemann, 1982:41) writes that the Old Testament is never interested in abstract issues like how evil came into the world, but is more concerned with faithful responses and effective coping. 
established the rules; those choosing to abide by them, be they men or women, live (Allen, 1999:304-305). Sealing their own ruin, the disobedient like Athaliah perish.

\section{List of references}

ALLEN, L.C. 1999. The First and Second Books of Chronicles. (In The new interpreter's Bible: A commentary in twelve volumes. Vol. III. L.E. Keck, convener. Nashville: Abingdon. p. 297-659.)

ALTER, R. 1981. The art of Biblical narrative. New York: Basic Books.

ANDREASEN, N.E.A. 1983. The role of queen mother in Israelite society. Catholic Biblical Quarterly, 45(2):179-194.

ANON. 1971a. Athaliah. (In Encyclopaedia Judaica. Jerusalem: Keter. p. 3:691693.)

ANON. 1971b. Salome Alexandra. (In Encyclopaedia Judaica. Jerusalem: Keter 14:691-693.)

BABYLONIAN TALMUD. 1965. London: Soncino.

BARRICK, W.B. 2001. Another shaking of Jehoshaphat's family tree: Jehoram and Ahaziah once again. Vetus Testamentum, 51(1):9-25.

BEN-BARAK, Z. 1994. The status and right of the gebira. (In Brenner, A., ed. A feminist companion to Samuel and Kings. Sheffield: Sheffield Academic Press. p. 170-185.)

BLENKINSOPP, J. 1993. Wisdom in the Chronicler's work. (In In search of wisdom: Essays in memory of John G. Gammie. Louisville, KY: Westminster/John Knox. p. 19-30.)

BOWEN, N.R. 2001. The quest for the historical Gebira. Catholic Biblical Quarterly, 63(4):597-618.

BRENNER, A. 1985. The Israelite woman: Social role and literary type in biblical narrative. Sheffield: JSOT.

BRIGHT, J. 1981. A history of Israel. Philadelphia: Westminster.

BRUEGGEMANN, W. 1982. Genesis. Atlanta: John Knox.

CAMP, C.V. 1992. 1 and 2 Kings. (In The Women's Bible commentary. Louisville, KY: Westminster/John Knox. p. 96-109.)

DILLARD, R.B. 1987. 2 Chronicles. Waco, TX: Word.

EVANS, M. 1983. Women in the Bible. Exeter: Paternoster.

FEWELL, D.N., \& GUNN, D.M. 1993. Gender, power, and promise: The subject of the Bible's first story. Nashville, TN: Abingdon.

GINZBERG, L. 1968. Legends of the Jews. 6 vols. London: Soncino.

HAMILTON, V.P. 2001. Handbook on the Historical Books: Joshua, Judges, Ruth, Samuel, Kings, Chronicles, Ezra-Nehemiah, Esther. Grand Rapids, MI: Baker Academic.

HOBBS, T.R. 1985. 2 Kings. Waco, TX: Word.

JAMES, F. 1939. Personalities of the Old Testament. New York: Charles Scribner's Sons.

JOSEPHUS, F. 1981. Antiquities of the Jews. Complete Works. W. Whiston, trans. Grand Rapids, MI: Kregel.

KATZENSTEIN, H.J. 1955. Who were the parents of Athaliah? Israel Exploration Journal, 5(3):194-197.

KAUFMANN. Y. 1947. The religion of Israel (Toledot ha-Emunah ha Yisre'elit). Eight volumes in four. Hebrew. Jerusalem: Musad Bialik. 
LOCKYER, H. 1967. The women of the Bible. Grand Rapids, MI: Zondervan.

LOSTRACCO, J., \& WILKERSON, G. 1998. Analyzing short stories. Dubuque, IA: Kendall/Hunt.

NELSON, R.D. 1987. First and second Kings. Atlanta: John Knox Press.

NICHOLSON, E.W. 1965. The meaning of the expression am haeretz in the Old Testament. Journal of Semitic Studies, (10):59-66.

RACINE, J. 1960. Five plays translated into English verse. K. Muir, trans. New York: Hill \& Wang.

RUTH RABBAH. 1939. London: Soncino.

SCHULTE, H. 1994. The end of the Omride dynasty: Social-ethical observations on the subject of power and violence. Semeia, 66:133-148.

SLOTKI, I.W. 1950. Kings. London: Soncino.

THIEL, W. 1992. "Athaliah". (In Anchor Bible Dictionary. Vol. 1. New York: Doubleday. p. 511-512.)

TRIBLE, P. 1973. Departriarchalizing in biblical interpretation. Journal of the American Academy of Religion, 41:30-48.

VON RAD, G. 1966. The Levitical sermon in I and II Chronicles. (In Von Rad, G., ed. The problem of the hexateuch and other essays. New York: McGraw Hill. p. 267-280.)

\section{Key concepts:}

Athaliah

biblical narration

Jehoiada and Jehosheba

Joash

political climate in 9th-century Judah

\section{Kernbegrippe:}

Atalia

Bybelse vertellings

Joas

Jojada en Jehoseba

politieke klimaat: 9de-eeuse Juda 
Athaliah, a treacherous queen: A careful analysis of her story ... 